\title{
PENGARUH DISIPLIN KERJA DAN MOTIVASI KERJA TERHADAP KINERJA KARYAWAN PADA PT. SGI
}

\author{
Chusnah, Heni Purwanti \\ Fakultas Ekonomi dan Bisnis Jurusan Manajemen \\ Universitas Islam As-Syafi'iyah, Jakarta \\ chusnahchoyib@yahoo.com
}

\begin{abstract}
In this study the authors took the title "The Effect of Work Dicipline and Motivation on employee performance on PT. SGI ". The purpose of this study was to determine the effect of work dicipline, and motivation on employee performance partially or simultaneously. Based on the results of data analysis and partial discussion of work dicipline (X1) a positive and significant effect on employee performance. Motivation (X2) partially has a positive and significant effect on employee performance. Simultaneously work dicipline and motivation have positive and significant effect on employee performance.

The results of the study simultaneously from the influence of work dicipline and motivation on employee performance obtained 53.4\% while the remaining $46.6 \%$ was influenced by other variables not included in this study.
\end{abstract}

Keywords: Work Dicipline, Motivation, and Employee Performance

\begin{abstract}
Abstrak
Pada penelitian ini peyusun mengambil judul "Pengaruh Disiplin Kerja dan Motivasi Kerja Terhadap Kinerja Karyawan PT. SGI". Tujuan penelitian ini adalah mengetahui pengaruh disiplin kerja, dan motivasi terhadap kinerja karyawan secara parsial maupun simultan. Berdasarkan hasil analisis data dan pembahasan secara parsial disiplin kerja (X1) berpengaruh positif dan signifikan terhadap kinerja karyawan. Motivasi (X2) secara parsial berpengaruh positf dan signifikan terhadap kinerja karyawan. Secara simultan disiplin kerja dan motivasi berpengaruh positif dan signifikan terhadap kinerja karyawan. Hasil penelitian secara serentak dari pengaruh disiplin kerja dan motivasi terhadap kinerja karyawan diperoleh $53,4 \%$ sedangkan sisanya $46,6 \%$ dipengaruhi oleh variable lain yang tidak turut diteliti dalam penelitian ini.
\end{abstract}

Kata Kunci : Disiplin Kerja, Motivasi, dan Kinerja Karyawan 


\section{Pendahuluan}

\section{Latar Belakang}

Sumber daya manusia merupakan faktor sentral dalam sebuah organisasi. Apapun bentuk serta tujuannya, organisasi dibuat berdasarkan berbagai visi untuk kepentingan manusia dan dalam pelaksanaan misinya dikelola dan diurus oleh manusia. Jadi, manusia merupakan faktor strategis dalam semua kegiatan organisasi. Walaupun banyak sumber daya, sarana dan prasarana lainnya, tanpa ada sumber daya manusia maka kegiatan perusahaan tersebut tidak akan berjalan dengan baik. Selain itu sumber daya manusia juga merupakan faktor pengerak dan penentu jalannya suatu organisasi dalam mencapai keberhasilan atau tujuan organisasi.

PT SGI berdiri pada tahun 1996 dan memulai produksi pada bulan Januari 1997. PT SGI memproduksi Part Metal dan Komponen (Forging dan Machining) untuk industri otomotif roda dua dan roda empat, baik pasar lokal maupun ekspor. Berkembangnya PT SGI dipengaruhi oleh beberapa faktor antara lain kemampuan memproduksi komponen yang bermutu tinggi dengan berpedoman pada teknik dari perusahaan induk di Jepang, kemampuan memenuhi keinginan pelanggan sehingga mendapat kepercayaan dan kepuasan pelanggan. Untuk mencapai mutu yang baik PT SGI menggunakan material terbaik serta mesin berteknologi tinggi sesuai standard untuk memenuhi permintaan customer.

PT SGI mempunyai visi "sebagai produsen yang handal, dapat di percaya serta dapat memenuhi kebutuhan pelanggan, yang pada akhirnya menjadi perusahaan komponen automotif yang di akui dunia”.

Pada PT. SGI banyak karyawan yang kurang memahami atas peraturan yang ada sehingga menimbulkan kurangnya kesadaran karyawan untuk mentaati peraturan yang berlaku di perusahaan, kurangnya rasa tanggung jawab terhadap pekerjaan

Dalam fenomena yang terjadi pada karyawan di PT. SGI melalui wawancara saat ini terlihat kurangnya mempunyai rasa tanggung jawab terhadap pekerjaan, selalu mementingkan diri sendiri, tidak pernah memberi contoh yang baik, dan kurangnya rasa ketegasan dalam memimpin. Sehingga menimbulkan rendahnya disiplin kerja karyawan dalam PT. SGI. Karena keberhasilan suatu organisasi atau perusahaan dalam meningkatkan kedisiplinan karyawan, sukses tidaknya karyawan dalam prestasi kerja dapat dipengaruhi oleh motivasi yang diberikan oleh pimpinan perusahaan.

Hasibuan (2018:193) kedisiplinan menyatakan bahwa "Kesadaran dan kesediaan seseorang mentaati semua peraturan perusahaan dan norma-norma sosial yang berlaku”. Selain itu banyak karyawan yang datang tidak tepat waktu, menunda tugas kantor, tidak hadir tanpa keterangan, tidak bisa memanfaatkan sarana kantor dengan baik dan masih adanya sebagian karyawan yang meninggalkan tugas pada jam kerja tanpa keterangan yang sah, maka dari itu pentingnya disiplin kerja diterapkan pada suatu perusahaan, agar karyawan dapat bekerja sesuai dengan aturan dan ketentuan yang telah ditetapkan perusahaan, sehingga dapat memberi dampak positif bagi perkembangan dan kenajuan perusahaan.

Feriyanto dkk (2015:71) menyatakan bahwa Motivasi adalah "Suatu sugesti atau dorongan yang muncul karena diberikan oleh seseorang kepada orang lain atau dari diri sendiri". Kurangnya motivasi yang diberikan perusahaan menyebabkan berkurangnya semangat karyawan dalam melakukan pekerjaan, tidak adanya imbalan yang pantas membuat karyawan bekerja ala kadarnya dan ini berimbas kepada pencapaian perusahaan 
tiap bulannya padahal timbal balik yang setimpal bisa menjadikan acuan motivasi yang diberikan perusahaan agar karyawan bisa bekerja lebih optimal.

Adanya motivasi akan sangat berpengaruh terhadap psikologis seorang karyawan, karena dengan memberikan motivasi kepada karyawan dalam bekerja maka akan timbul rasa percaya diri yang mana akan menimbulkan suatu semangat dalam diri seseorang untuk bekerja lebih baik lagi.

Wibowo (2016:2) menyatakan bahwa kinerja karyawan adalah "Nilai serangkaian perilaku yang memberikan kontribusi, baik secara positif maupun negative, pada penyelesaian tujuan organisasi". Kinerja karyawan yang belum optimal dan mengalami penurunan tiap bulannya. Tinggi rendahnya kinerja karyawan dipengaruhi dua faktor yaitu disiplin dan motivasi.

Dengan permasalahan-permasalahan tersebut tentunya berpengaruh terhadap kinerja pegawai karena kinerja pegawai berkenaan dengan derajat pencapaian tujuan organisasi, baik secara implisit maupun eksplisit, yaitu jauh rencana dapat dilaksanakan dan seberapa jauh tujuan dapat tercapai bagaimana mungkin tujuan yang ditetapkan dapat tercapai, apabila masih banyak pegawai yang kurang peduli dengan tanggung jawabnya.

Berdasarkan latar belakang di atas, maka peneliti tertarik untuk melakukan penelitian dengan judul "Pengaruh Disiplin Kerja Dan Motivasi Kerja Terhadap Kinerja Karyawan PT. SGI".

\section{Perumusan Masalah}

Adapun permasalahan yang akan dibahas dalam penelitian yang dilakukan di PT SGI dapat dirumuskan sebagai berikut:

1. Apakah disiplin kerja berpengaruh terhadap kinerja karyawan di PT. SGI ?

2. Apakah motivasi kerja berpengaruh terhadap kinerja karyawan di PT. SGI?

3. Apakah displin kerja dan motivasi kerja secara simultan berpengaruh terhadap kinerja karyawan di PT. SGI?

\section{Tujuan Penelitian}

Berdasarkan rumusan masalah yang ada, maka tujuan penelitian yang dilakukan di PT SGI adalah:

1. Untuk mengetahui seberapa besar pengaruh disiplin kerja terhadap kinerja karyawan di PT. SGI.

2. Untuk mengetahui seberapa besar pengaruh motivasi kerja terhadap kinerja karyawan di PT. SGI.

3. Untuk mengetahui seberapa besar pengaruh disiplin kerja dan motivasi kerja secara simultan terhadap kinerja karyawan di PT. SGI.

\section{Tinjauan Pustaka}

\section{Disiplin Kerja}

Hasibuan (2018:193) kedisiplinan menyatakan bahwa "Kesadaran dan kesediaan seseorang mentaati semua peraturan perusahaan dan norma-norma sosial yang berlaku”. 


\section{Indikator Disiplin Kerja}

1. Frekuensi kehadiran.

2. Ketepatan kerja.

3. Mengenakan pakaian kerja dan tanda pengenal.

4. Seluruh karyawan wajib memakai pakaian yang rapih dan sopan, dan mengenakan tanda pengenal selama menjalankan tugas kedinasan.

5. Ketaatan pada standar kerja.

6. Etika kerja.

\section{Motivasi Kerja}

Samsudin (2010:281) mengemukakan bahwa :

Motivasi adalah proses mempengaruhi atau mendorong dari luar terhadap seseorang atau kelompok kerja agar mereka mau melaksanakan suatu yang telah ditetapkan. Motivasi atau dorongan dimaksudkan sebagai desakan yang alami untuk memuaskan dan mempertahankan kehidupan.

\section{Indikator Motivasi Kerja}

1. Fisiologis atau kebutuhan fisik, ditujukan dengan pemberian gaji yang layak kepada pegawai, pemberian bonus, uang makan, uang transportasi, fasilitas perumahan dan lain sebagainya.

2. Keamanan, ditunjukan dengan fasilitas keamanan dan keselamatan kerja yang diantaranya seperti adanya jaminan social tenaga kerja, dana pension. Tunjangan kesehatan, asuransi kesehatan, dan perlengkapan keselamatan kerja.

3. Penghargaan, ditunjukan dengan pengakuan dan penghargaan berdasarkan kemampuan, yaitu kebutuhan untuk dihormati dan dihargai oleh karyawan lain dan pimpinan terhadap prestasi kerjanya.

4. Aktualisasi diri, ditunjukan dengan sifat pekerjaan yang menarik dan menantang, dimana karyawan tersebut akan mengerahkan kecakapannya, kemampuan, keterampilan, dan potensinya.

\section{Kinerja}

Mangkunegara (2011:67) mengemukakan bahwa :

Kinerja (prestasi kerja) adalah hasil kerja secara kualitas dan kuantitas yang dicapai oleh seorang pegawai dalam melaksanakan tugasnya sesuai dengan tanggung jawab yang diberikan kepadanya.

\section{Indikator Kinerja}

1. Mempunyai kemampuan untuk melaksanakan tugas.

2. Berusaha untuk meningkatkan hasil kerja yang dicapai.

3. Meningkatkan semangat dalam bekerja.

4. Senantiasa mengembangkan diri untuk meningkatkan kemampuan kerja.

5. Selalu berusaha untuk meningkatkan mutu lebih baik dari yang telah lalu.

6. Perbandingan antara hasil yang dicapai dengan keseluruhan sumber daya yang digunakan. 


\section{Hipotesis}

H1 : Disiplin kerja berpengaruh positif dan signifikan terhadap kinerja karyawan PT. SGI

H2 : Motivasi Berpengaruh Positif dan Signifikan terhadap Kinerja Karyawan PT. SGI

H3 : Disiplin kerja dan motivasi secara bersama-sama berpengaruh positif dan signifikan terhadap kinerja karyawan PT. SGI

\section{Kerangka Pemikiran}

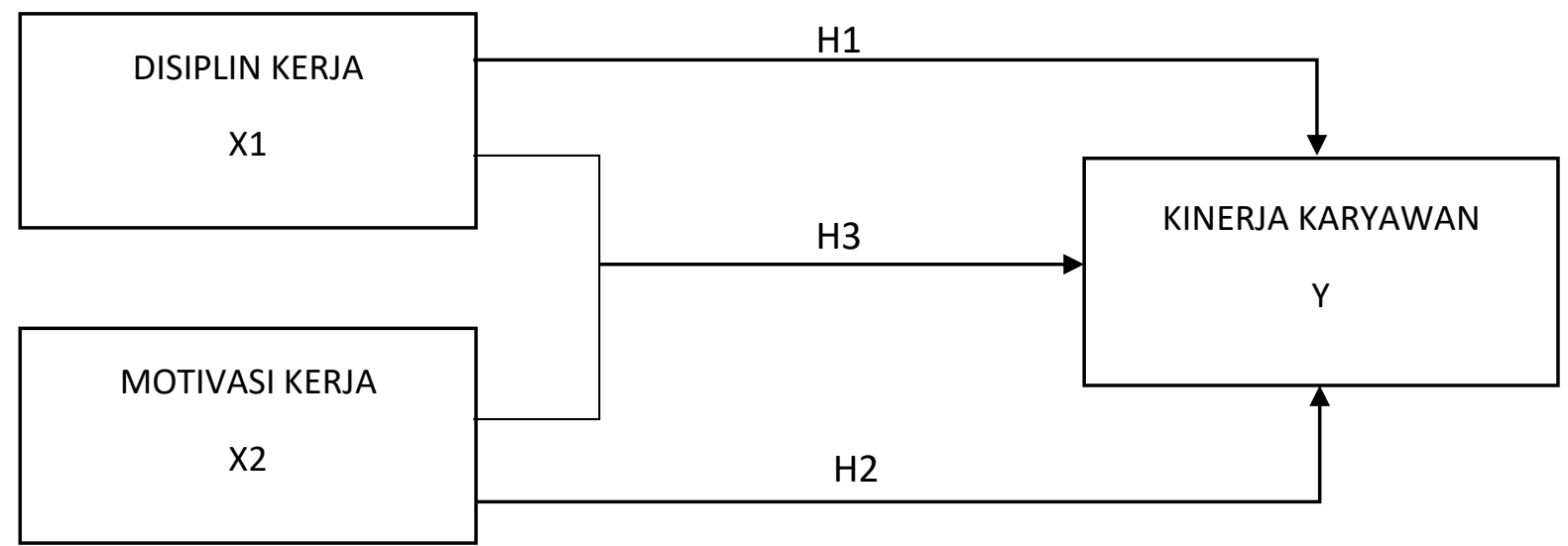

\section{Metode Peneliltian}

\section{Populasi, Sampel dan Sampling}

Populasi dalam penelitian ini adalah seluruh karyawan PT. SGI sejumlah 50 orang yang terdiri dari Produksi, Admin. Dalam penelitian ini seluruh populasi dijadikan sampel yaitu 50 karyawan. Penentuan Sample dalam penelitian ini menggunakan probability sampling yaitu teknik sampling yang memberikan peluang yang sama bagi setiap unsur populasi untuk dipilih menjadi anggota sampel.

\section{Metode Analisis Data}

Teknik analisis data dari variabel penelitian yang sudah diketahui yaitu variabel disiplin kerja, motivasi dan kinerja karyawan, bisa dihitung dengan menggunakan aplikasi SPSS, dalam penelitian ini menggunakan perhitungan uji instrument penelitian, uji asumsi klasik, uji multikolinearitas, uji heteroskedastisitas, analisis regresi, analisis korelasi, koefisien determinasi, uji hipotesa yaitu uji t dan $\mathrm{f}$. 


\section{Hasil Penelitian}

\section{Uji Validitas}

Pengujian validitas dapat dilakukan dengan cara mengkorelasikan masing-masing faktor atau variabel dengan total faktor atau variabel tersebut dengan menggunakan korelasi (r) product moment.

Kriteria pengujian untuk menerima atau menolak hipotesis adanya pernyataan yang valid atau tidak dapat dilakukan dengan:

$\mathrm{H}_{0}: \mathrm{r}=0$, tidak terdapat data yang valid pada tingkat kesalahan $(\alpha) 5 \%$.

$\mathrm{H}_{1}: r \neq 0$, terdapat data yang valid pada tingkat kesalahan $(\alpha) 5 \%$.

Hipotesa nol $\left(\mathrm{H}_{0}\right)$ diterima apabila $\mathrm{r}_{\text {hitung }}<\mathrm{r}$ tabel, demikian sebaliknya hipotesa alternatif $\left(\mathrm{H}_{1}\right)$ diterima apabila $\mathrm{r}_{\text {hitung }}>\mathrm{r}_{\text {tabel. }}$.

\section{Uji Reliabilitas}

Uji reliabilitas menunjukkan tingkat kemantapan, keajegan dan ketepatan suatu alat ukur atau uji yang digunakan untuk mengetahui sejauh mana pengukuran relatif konsisten apabila dilakukan pengukuran ulang. Uji ini digunakan untuk mengetahui sejauh mana jawaban seseorang konsisten atau stabil dari waktu ke waktu. Teknik pengujian reliabilitas adalah dengan menggunakan nilai koefisien reliabilitas alpha. Kriteria pengambilan keputusannya adalah apabila nilai dari koefisien reliabilitas alpha lebih besar dari 0,6 maka variabel tersebut sudah reliabel (handal).

\section{Uji Normalitas}

Uji ini dilakukan untuk mengetahui apakah nilai residual tersebar normal atau tidak. Prosedur uji dilakukan dengan uji Kolmogorov-Smirnov, Dari hasil perhitungan didapat nilai sig. sebesar 0.917 atau lebih besar dari 0.05; maka ketentuan $\mathrm{H}_{0}$ diterima yaitu bahwa asumsi normalitas terpenuhi. Berdasarkan uji P-P Plot didapatkan bahwa titik - titik data sudah menyebar mengikuti garis diagonal, sehingga dikatakan bahwa residual sudah menyebar secara distribusi normal.

\section{Uji Multikolinieritas}

Uji Multikolinieritas ini dilakukan untuk mengetahui bahwa tidak terjadi hubungan yang sangat kuat atau tidak terjadi hubungan linier yang sempurna atau dapat pula dikatakan bahwa antar variabel bebas tidak saling berkaitan. Cara pengujiannya adalah dengan membandingkan nilai Tolerance yang didapat dari perhitungan regresi berganda, apabila nilai tolerance $<0,1$ maka terjadi multikolinearitas. Pada hasil pengujian didapat bahwa keseluruhan nilai tolerance $>0,1$ sehingga dapat disimpulkan bahwa tidak terjadi multikolinearitas antar variabel bebas.

Uji multikolinearitas dapat pula dilakukan dengan cara membandingkan nilai VIF (Variance Inflation Faktor) dengan angka 10. Jika nilai VIF > 10 maka terjadi multikolinearitas. Dari hasil pengujian tersebut dapat disimpulkan bahwa tidak terjadi 
multikolinearitas antar variabel bebas. Dengan demikian uji asumsi tidak adanya multikolinearitas dapat terpenuhi.

\section{Uji Koefisien Determinasi}

Untuk mengetahui besar kontribusi variabel bebas (Disiplin Kerja (X1) dan Motivasi (X2)) terhadap variabel terikat (Kinerja Karyawan) digunakan nilai $\mathrm{R}^{2}$, Koefisien determinasi digunakan untuk menghitung besarnya pengaruh atau kontribusi variabel bebas terhadap variabel terikat. Dari analisis diperoleh hasil adjusted $\mathrm{R}^{2}$ (koefisien determinasi) sebesar 0,534. Artinya bahwa 53,4\% variabel Kinerja Karyawan akan dipengaruhi oleh variabel bebasnya, yaitu Disiplin Kerja $\left(\mathrm{X}_{1}\right)$ dan Motivasi (X2). Sedangkan sisanya 46,6\% variabel Kinerja Karyawan akan dipengaruhi oleh variabelvariabel yang lain yang tidak dibahas dalam penelitian ini.

Selain koefisien determinasi juga didapat koefisien korelasi yang menunjukkan besarnya hubungan antara variabel bebas yaitu Disiplin Kerja dan Motivasi dengan variabel Kinerja Karyawan, nilai R (koefisien korelasi) sebesar 0.744, nilai korelasi ini menunjukkan bahwa hubungan antara variabel bebas yaitu Disiplin Kerja $\left(\mathrm{X}_{1}\right)$ dan Motivasi (X2) dengan Kinerja Karyawan termasuk dalam kategori kuat karena berada pada selang $0,6-0,8$.

\section{Uji T}

Uji t (parsial) digunakan untuk menunjukan apakah suatu variabel independen mempengaruhi varianel dependen. Kriteria pengujian dengan tingkat signifikan $(a)=0,05$ di tentukan sebagai berikut: apabila $t_{\text {hitung }}>t_{\text {tabel }}$, maka Ho ditolak dan Ha diterima, sedangkan dengan derajat kebebasan (df) n-k-1 atau 80-2-1 = 77 ( $\mathrm{n}$ adalah jumlah data dan $\mathrm{k}$ adalah jumlah variabel independen). Hasil diperoleh untuk $t_{\text {tabel }}$ sebesar 1,991, adapun hasil uji t.

1. Disiplin Kerja

Berdasarkan tabel 4.18 maka diperoleh taraf signifikan Disiplin Kerja 0,000 dan $t_{\text {hitung }}$ sebesar 2,367 menunjukan bahawa signifikan $0,000<0,05$ dan $t_{\text {hitung }} 2,367$

$>t_{\text {tabel }}$ 2,042 yang berarti bahwa disiplin kerja signifikan terhadap kinerja karyawan. Maka dapat disimpulkan bahwa Ha diterima, artinya disiplin kerja berpengaruh positif dan signifikan terhadap kinerja karyawan PT SGI

2. Motivasi Kerja

Berdasarkan tabel 4.18 maka diperoleh taraf signifikan motivasi kerja 0,001 dan $t_{\text {hitung }}$ sebesar 3,243 menunjukan bahwa signifikan 0,001 $<0,05$ dan $t_{\text {hitung }}$ $3,243>t_{\text {tabel }}$ 2,042 yang berarti bahwa motivasi kerja signifikan terhadap kinerja karyawan. Maka dapat disimpulkan bahwa Ha diterima artinya disiplin kerja berpengaruh positif dan signifikan terhadap kinerja karyawan PT. SGI

\section{Uji F}

Pengujian $\mathrm{F}$ atau pengujian model digunakan untuk mengetahui apakah hasil dari analisis regresi signifikan atau tidak, dengan kata lain model yang diduga tepat/sesuai atau tidak. Jika hasilnya signfikan, maka $\mathrm{H}_{0}$ ditolak dan $\mathrm{H}_{1}$ diterima. Sedangkan jika 
hasilnya tidak signifikan, maka $\mathrm{H}_{0}$ diterima dan $\mathrm{H}_{1}$ ditolak. Hal ini dapat juga dikatakan sebagai berikut :

a. Jika sig $>0,05$ maka $\mathrm{H}_{0}$ diterima atau $\mathrm{H}_{1}$ ditolak.

b. Jika sig $<0,05$ maka $\mathrm{H}_{0}$ ditolak atau $\mathrm{H}_{1}$ diterima.

Berdasarkan Tabel 4.19 nilai $\mathrm{F}$ hitung sebesar 29,105. Sedangkan F tabel $(\alpha=$ $0.05 ;$ db regresi $=2:$ db residual $=47)$ adalah sebesar 3,195. Karena $F$ hitung $>F$ tabel yaitu 29,105 $>3,195$ atau nilai $\operatorname{sig} \mathrm{F}(0,000)<\alpha=0.05$ maka model analisis regresi adalah signifikan. Hal ini berarti H0 ditolak dan $\mathrm{H} 1$ diterima sehingga dapat disimpulkan bahwa variabel terikat (Kinerja Karyawan) dapat dipengaruhi secara signifikan oleh variabel bebas (Disiplin Kerja (X1), Motivasi (X2).

\section{Pembahasan}

\section{Pengaruh Simultan Disiplin Kerja (X1) dan Motivasi (X2) terhadap Kinerja Karyawan}

Uji F dilakukan untuk menguji hipotesis penelitian yang menyatakan bahwa terdapat pengaruh yang signifikan antara Disiplin Kerja $\left(\mathrm{X}_{1}\right)$ dan Motivasi (X2) terhadap Kinerja Karyawan secara simultan. Pengujian yang dilakukan memperoleh nilai signifikansi $\mathrm{F}$ sebesar 0,000 sehingga signifikansi $\mathrm{F}<\alpha$ yaitu $0,000<0,05$. Hal ini menunjukkan bahwa $\mathrm{H} 0$ ditolak, artinya terdapat pengaruh yang signifikan antara variabel Disiplin Kerja $\left(\mathrm{X}_{1}\right)$ dan Motivasi (X2) terhadap Kinerja Karyawan secara simultan. Jika dilihat dari nilai Adjust $R$ Square yang diperoleh, maka Disiplin Kerja $\left(\mathrm{X}_{1}\right)$ dan Motivasi (X2) memiliki pengaruh sebanyak 53,4\% dalam mempengaruhi Kinerja Karyawan, sedangkan sisanya $46,6 \%$ dipengaruhi oleh variabel lain yang tidak diteliti dalam penelitian ini.

\section{Pengaruh Disiplin Kerja $\left(\mathrm{X}_{1}\right)$ terhadap Kinerja Karyawan ( $\left.\mathrm{Y}\right)$}

Pada hasil analisis menggunakan metode regresi berganda, diperoleh nilai $\mathrm{t}$ hitung sebesar 2,367 dengan sig. t sebesar 0,022 dengan t tabel sebesar 2,012 sehingga variabel Disiplin Kerja memiliki pengaruh terhadap Kinerja Karyawan. Jika dilihat dari nilai signifikansi t sebesar 0,022 lebih kecil dari alpha yang dipakai yaitu 0,022<0,05. Sehingga dapat disimpulkan Disiplin Kerja mempunyai pengaruh yang signifikan terhadap Kinerja Karyawan.

\section{Pengaruh Motivasi (X2) terhadap Kinerja Karyawan (Y)}

Pada hasil analisis menggunakan metode regresi berganda, diperoleh nilai $\mathrm{t}$ hitung sebesar 3,243 dengan $t$ tabel sebesar 2,012 sehingga variabel Motivasi memiliki pengaruh yang signifikan terhadap Kinerja Karyawan. Jika dilihat dari nilai signifikansi t sebesar 0,002 lebih kecil dari alpha yang dipakai yaitu $0,002<0,05$. Sehingga dapat disimpulkan Motivasi mempunyai pengaruh yang signifikan terhadap Kinerja Karyawan.

\section{Penutup}

\section{Simpulan}

1. Pengaruh secara simultan (bersama-sama) tiap variabel bebas terhadap Kinerja Karyawan dilakukan dengan pengujian F-test. Dari hasil analisis regresi linier berganda diperoleh variabel bebas mempunyai pengaruh yang signifikan secara 
simultan terhadap kinerja karyawan. Sehingga dapat disimpulkan bahwa pengujian terhadap hipotesis yang menyatakan bahwa adanya pengaruh secara bersama-sama (simultan) variabel bebas terhadap variabel Kinerja Karyawan dapat diterima.

2. Untuk mengetahui pengaruh secara individu (parsial) variabel bebas (Disiplin Kerja (X1) dan Motivasi (X2)) terhadap Kinerja Karyawan dilakukan dengan pengujian ttest. Berdasarkan pada hasil uji didapatkan bahwa terdapat enam variabel yang mempunyai pengaruh signifikan terhadap Kinerja Karyawan yaitu Disiplin Kerja (X1) dan Motivasi (X2).

3. Berdasarkan pada hasil uji t didapatkan bahwa variabel Motivasi mempunyai nilai $\mathrm{t}_{\text {hitung }}$ dan koefisien beta yang paling besar. Sehingga variabel Motivasi mempunyai pengaruh yang paling kuat dibandingkan dengan variabel yang lainnya maka variabel Motivasi mempunyai pengaruh yang dominan terhadap Kinerja Karyawan.

\section{Saran}

1. Dilihat dari hasil korelasi berganda disiplin kerja dan motivasi memiliki hubungan yang positif dan kuat terhadap kinerja karyawan sehingga perusahaan disarankan untuk mempertahankan disiplin kerja dan motivasi kerja karyawannya.

2. Berdasarkan jawaban responden disiplin kerja diketahui pernyataan karyawan yang tidak mentaati kerja dan melakukan kesalahan akan dikenakan sanksi di PT. SGI mendapatkan skor paling rendah jadi diharapkan perusahaan untuk memberikan sanksi-sanksi yang jelas terhadap kesalahan yang dilakukan dan perusahaan juga harus lebih meningkatkan ketegasan dalam memberikan sanksi kepada karyawan.

3. Berdasarkan jawaban responden motivasi diketahui pernyataan kerja lembur yang optimal dapat mencapai target yang ditetapkan perusahaan mendapatkan skor paling rendah, sebaliknya perusahaan lebih memperhatikan jam lembur kerja karena akan berpengaruh terhadap pencapaian target yang kurang optimal.

4. Berdasarkan jawaban responden kinerja karyawan pernyataan saya mampu bekerja sesuai standar kerja yang ditetapkan, dengan bekerja sesuai standar kerja diharapkan dapat membantu dalam mengatasi masalah yang ada diperusahaan.

5. Mengingat variabel bebas dalam penelitian ini merupakan hal yang sangat penting dalam mempengaruhi Kinerja karyawan diharapkan hasil penelitian ini dapat dipakai sebagai acuan bagi peneliti selanjutnya untuk mengembangkan penelitian ini dengan mempertimbangkan variabel-variabel lain yang merupakan variabel lain diluar variabel yang sudah masuk dalam penelitian ini. 


\section{Referensi}

Al-Qur'an

Arikuntoro, S 2011. Prosedur Penelitian. Edisi VII, PT. Rineka Jakarta.

Badriyyah, M. 2015. Manajemen Sumber Daya Manusia. CV. Pustaka Setia Bandung.

Djudi, M. 2017. Pengaruh Motivasi dan Disiplin Kerja Terhadap Kinerja Karyawan PT. Karoseri Tentrem Sejahtera Kota Malang

Friyanto, Andri. 2015. Pengantar Manajemen. Mediatera. Kebumen

Fahmi, I. 2016. Pengantar Manajemen Sumber Daya Manusia Konsep \& Kinerja.Mitra Wacana Media. Jakarta.

Ghozali, I. 2016. Aplikasi Analisis Multivariant Dengan Program IBM SPSS 20.Universitas Diponogoro. Semarang.

Handoko, T H. 2014. Manajemen Personalia dan Sumber Daya Manusia. BPFE. Yogyakarta.

Hasibuan, M S.P. 2016. Manajemen Sumber Daya Manusia. Edisi 20, Bumi Aksara Jakarta.

Hasibuan, M S P. 2016. Manajemen Sumber Daya Manusia. Edisi 19, PT. Bumi Aksara Jakarta.

Heriyanto. 2016. Pengaruh Motivasi dan Disiplin Kerja Terhadap Kinerja Pegawai

Mathis, R L Dan John H J. 2012. Manajemen Sumber Daya Manusia. Edisi 1, Salemba Empat Jakarta.

Marwansyah. 2016. Manajemen Sumber Daya Manusia. Alfabeta. Bandung.

Mangkunegara, Anwar P. 2015. Manajemen Sumber Daya Manusia Perusahaan. Edisi 8, PT. Remaja Rosdakarya. Bandung.

Mangkunegara, Anwar P. 2014. Evaluasi Kinerja Sumber Daya Manusia. Edisi 7, Refika Aditama. Bandung.

Ruhana Ika. 2015. Motivasi Kerja dan Disiplin Kerja Terhadap Kinerja Karyawan PT.Pattindo Malang.

Sujarweni, V.W.2015.Statistik Bisnis dan Ekonomi. Edisi 1, Pustaka Baru Prestasi Yogyakarta.

Sugiyono, 2017. Metode Penelitian Kombinasi. Edisi 8, Alfabeta. Bandung.

Sugiyono, 2015. Metode Penelitian Pendidikan. Edisi 6, Alfabeta. Bandung.

Suwatno, dan Donni Juni P. 2016. Manajemen Sumber Daya Manusia dalam Organisasi Publik dan Bisnis. Alfabeta. Bandung.

Sutrisno. 2016. Pengaruh Motivasi dan Disiplin Kerja Terhadap Kinerja Pegawai dikantor Satua Polisi Pamong Praja Kota Semarang. 
KINERJA Jurnal Ekonomi dan Bisnis

Vol. 2 No. 1 - Desember 2019

Wibowo. 2016. Manajemen Kinerja. Edisi 5, Penerbit PT. Raja Grafindo Persada. Jakarta.

Wayan, L.B. 2015. Perilaku Organisasi. Penerbit Graha Ilmu. Yogyakarta. 